\title{
Trees enhance soil carbon sequestration and nutrient cycling in a silvopastoral system in south-western Nicaragua
}

\author{
Marcel R. Hoosbeek • Roy P. Remme • Graciela M. Rusch
}

Received: 1 December 2015/ Accepted: 14 November 2016/Published online: 23 November 2016

(C) The Author(s) 2016. This article is published with open access at Springerlink.com

\begin{abstract}
Tree occurrence in silvopastoral systems of Central America has been under pressure for various reasons including attempts to improve grassland productivity and the need for wood. However, scattered isolated trees are also recognized to provide ecosystem services like shade, fodder and fruits that are important to cattle in the dry season. In addition, trees may enhance the climate change mitigation potential of silvopastoral systems through increased carbon (C) uptake and subsequent soil carbon sequestration. Through differences in plant traits like nutrient uptake, canopy structure and litter quality, tree species may have an effect on $\mathrm{C}$ and nutrient cycling. Due to a prevailing north-easterly wind in the study area, three distinct areas associated with the impact of tree litter deposition were identified: (1) open pasture-no tree litter deposition; (2) tree canopy-above and belowground tree litter; and (3) leaf litter cone-aboveground tree litter deposition. Furthermore, the effect of
\end{abstract}

M. R. Hoosbeek ( $\square)$

Department of Soil Quality, Wageningen University, P.O. Box 47, 6700 AA Wageningen, The Netherlands e-mail: marcel.hoosbeek@wur.nl

R. P. Remme

National Institute for Public Health and the Environment (RIVM), P.O. Box 1, 3720 BA Bilthoven, The

Netherlands

G. M. Rusch

Norsk institutt for naturforskning (NINA),

Postboks 5685 Sluppen, 7485 Trondheim, Norway tree species, Guazuma ulmifolia and Crescentia alata, were considered. The presence of trees, as compared to pasture, caused larger topsoil $\mathrm{C}, \mathrm{N}$ and $\mathrm{P}$ contents. In the subsoil, $\mathrm{C}$ content was also larger due to tree presence. Soil fractionation showed that tree-induced larger litter input subsequently increased free and occluded $\mathrm{OM}$ fractions and ultimately increased stabilized SOM fractions. Therefore, trees were found to enhance soil $\mathrm{C}$ sequestration in these silvopastoral systems. This is also supported by the soil respiration data. Although the respiration rates in the pasture subplots were lower than in the leaf litter subplots, the difference was not significant, which suggests that part of the extra $\mathrm{C}$ input to the leaf litter subplots stayed in the soil. Nutrient cycling was also enhanced by tree presence, but with a clear differentiation between species. C. alata (Jícaro) enhanced available and stabilized forms of organic N, while G. ulmifolia (Guácimo) enhanced available soil $\mathrm{P}$ and stabilized organic P.

Keywords Silvopastoral system - Leaf litter deposition · Soil carbon stabilization · Carbon sequestration · Guazuma ulmifolia $\cdot$ Crescentia alata

\section{Introduction}

Silvopastoral systems (SPS) are a major land use in Central America providing a wide range of ecosystem 
services including soil carbon (C) sequestration (Dagang and Nair 2003; Pagiola et al. 2007). This land use type is usually the result of forest conversion to neotropical pasture with the preservation of selected trees (Guevara et al. 1986; Harvey and Haber 1998). Next to pasture for cattle raising, the scattered isolated trees provide shade to cattle, firewood, wood for construction, and fodder and fruits that are important to cattle in the dry season when grassland production stops (Manning et al. 2006; Ospina et al. 2012; Rusch et al. 2014). In addition, SPS may be a component of the terrestrial carbon sink by fixing $\mathrm{CO}_{2}$ through photosynthesis into organic matter and the subsequent sequestration of organic matter in soil (Andrade et al. 2008; Ballantyne et al. 2012). Moreover, the presence of trees in these pastures is likely to enhance soil C sequestration not only in the topsoil (Casals et al. 2014), but also in the subsoil due to bioturbation and turnover of tree roots (Haile et al. 2010).

Attempts to increase pasture productivity and the need for wood has decreased the number of trees in SPS in the department of Rivas in south-west Nicaragua in recent decades. This has sparked a discussion on the role of trees for direct benefits to farmers like shade, firewood and fodder, but also on their role in the uptake of nutrients from deeper soil layers (Jobbágy and Jackson 2004), the distribution of nutrients through litter fall and effects on organic matter decomposition and carbon sequestration (Casals et al. 2014). Working in a Mediterranean Dehesa, Gallardo (2003) showed that isolated trees affect the spatial distribution of various nutrients, with for instance, $\mathrm{P}$ having a larger spatial range (beyond the canopy) as compared to $\mathrm{N}$ (within canopy projection). Also, through differences in plant traits like canopy structure and litter quality, tree species may have a local effect on $\mathrm{C}$ and nutrient cycling (Casals et al. 2014; Sánchez Merlos et al. 2005; Sardans and Peñuelas 2013). This local tree effect in combination with a prevailing north-easterly wind in the Rivas area created three distinct areas associated with the impact of tree litter deposition (Fig. 1): (1) open pasture-no tree litter deposition; (2) tree canopy-above and belowground tree litter; and (3) leaf litter coneaboveground tree litter deposition.

The decomposition of litter in each of the areas depends on environmental factors like temperature and moisture and on characteristics of the organic matter that may defer decomposition. These characteristics include intrinsic recalcitrance (litter quality - species dependent) and physical protection of organic matter by aggregation and chemical stabilization by the adsorption of organic matter onto mineral surfaces (Von Lützow et al. 2006), where the latter two depend on soil biological activity and chemical reactivity, respectively. Therefore, tree traits (Augusto et al. 2015; Casals et al. 2014) and the absence or occurrence of litter deposition may affect soil carbon stabilization mechanisms.

We hypothesized that litter deposition has different effects on soil $\mathrm{C}$, nitrogen $(\mathrm{N})$ and phosphorous (P) contents in the three tree litter deposition areas, with lower $\mathrm{C}$ and nutrient contents in open pasture (Casals et al. 2014), and higher soil respiration rates in the leaf litter cone area due to higher litter inputs. Through their effects on litter quality and soil C stabilization, we hypothesized tree species to have an effect on soil $\mathrm{C}, \mathrm{N}$ and $\mathrm{P}$ contents as well. We evaluated our hypothesis by selecting 12 suitable trees (plots) with about similar stature and by collecting soil samples at two depths from the three tree litter deposition areas per tree (subplots). We studied the impacts of two tree species, Guazuma ulmifolia (Guácimo) and Crescentia alata (Jícaro). Series of soil $\mathrm{CO}_{2}$ efflux measurements were also collected from the three tree litter deposition subplots.

\section{Methods}

Study area

This study was conducted in the municipalities of Belén and Rivas of the Rivas department in southwestern Nicaragua (UTM 16P; E 620780; N 1271756). The mean annual temperature of the Rivas department is $27^{\circ} \mathrm{C}$ and the mean annual precipitation is $1400 \mathrm{~mm}$ (INETER 2000). The natural vegetation of the region corresponds to a transitional tropical subhumid forest (Holdridge 2000) with semi-deciduous vegetation, and is referred to as seasonally dry tropical forest (Bullock et al. 1995), but the land has been widely modified over the past centuries and the present-day landscape of Rivas is dominated by pastures $(56.7 \%$ ) (Sánchez et al. 2004). Various SPS practices can be found in the Rivas area (e.g. hedgerows), but this study focused on isolated trees in pastures. Soils in the Rivas area were formed on 
Fig. 1 Schematic overview of the three sampling areas (subplots) associated with each tree (plot): (1) open pasture-no tree litter deposition; (2) tree canopy-above and belowground tree litter; and (3) leaf litter coneaboveground tree litter deposition
Prevailing wind direction

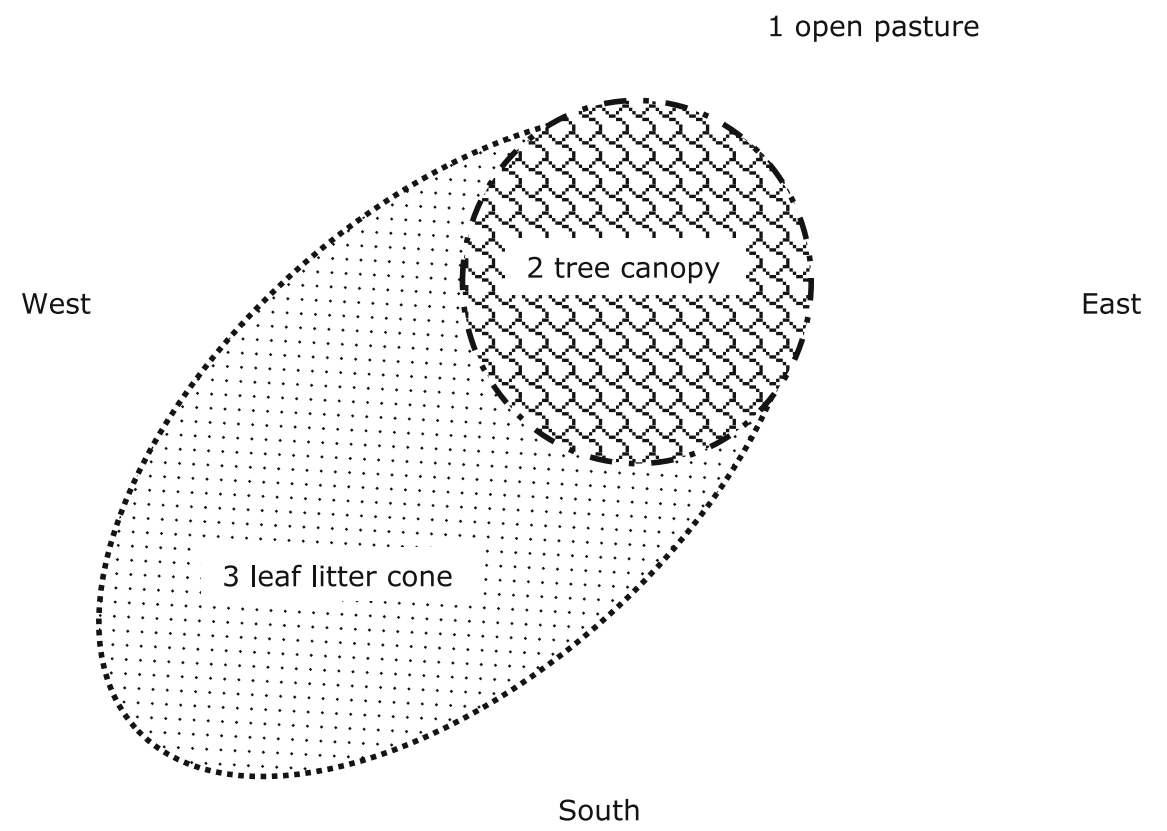

marine parent material of young Tertiary age which consists of clays and sands of varying thickness. The Rivas complex has been lightly folded and eroded, resulting in a landscape with rolling to steep hills. Alluvial fans with slopes of less than $10 \%$ were formed as a result of erosion in the hills. These areas are largely heavy-textured and range from clay loam on the fringes of valleys to heavy clay in the central areas. The clays are largely montmorillonitic, causing the formation of Vertisols (greatgroup Haplusterts) which swell upon wetting and form deep cracks upon drying. Only suitable trees on flat parts of the landscape were selected to eliminate the confounding effects of slope, i.e. recent erosion and/or sedimentation, in our research plots.

\section{Tree species}

Guazuma ulmifolia, locally known as Guácimo, is one of the most common trees in SPS of the Department of Rivas and is also one of the most used species as a source of forage and food in the dry season (Sánchez et al. 2004). It is a non-leguminous species (Flores et al. 1998) of a maximum height of about $8 \mathrm{~m}$ in the open field. It loses its leaves during the end of the dry season, in February and March. Flowers and fruits are produced largely in the leafless period in the dry season, between January and April (Cordero and Boshier 2003; Francis, 1991). The selected trees were all full-grown (about $8 \mathrm{~m}$ height) and based on their stature were estimated to be over 50 years of age.

Crescentia alata, also known as Jícaro, is common in the Rivas SPS and was selected next to G. ulmifolia because both species are about similar in size and crown architecture. A database with individuals of both species was available with information on location, size, land owner, etc. C. alata is a species that is tolerant to extreme (very wet and very dry) conditions. It produces flowers and large gourd-like seeds along its stem. The species does not lose its leaves throughout most of the dry season and is therefore semi-deciduous. Only near the end of the dry season the leaves are dropped, but new leaves are produced shortly thereafter, before the start of the rainy season (Cordero and Boshier 2003; Rockwood 1974). Flowers and fruits are produced all year round 
and are used as feed supplements. Similarly, the selected trees were all full-grown (about $8 \mathrm{~m}$ height) and based on their stature were estimated to be over 50 years of age.

\section{Experimental design}

Next to being positioned on stable and relatively flat landscape positions, trees (plots) were also selected on the basis of having sufficient distance to other trees, i.e. at least $25 \mathrm{~m}$, in order to avoid leaf litter deposition interactions. As mentioned, three sample areas per tree (subplots) were distinguished on the basis of environmental conditions and where leaf litter was deposited (Fig. 1): (1) open pasture-no tree litter deposition; (2) tree canopy-above and belowground tree litter; and (3) leaf litter cone-aboveground tree litter deposition. In each subplot, a soil pit of at least $50 \mathrm{~cm}$ depth was dug, in open pasture at least $10 \mathrm{~m}$ upwind from the tree crown perimeter; under the canopy, half way between the trunk and the projection of the crown perimeter; and centrally in the leaf litter cone, at least $3 \mathrm{~m}$ beyond the projection of the crown perimeter. Soil samples were taken at 0-20 and 20-40 cm soil depth between late August and early September of 2010. At each depth, three metal bulk density rings of $100 \mathrm{~cm}^{3}$ were inserted into the undisturbed pit face. In addition, next to the rings and at similar depth, soil was collected and bagged for soil fractionation and $\mathrm{C}, \mathrm{N}$ and $\mathrm{P}$ analysis in whole soil and all soil fractions. Soil samples were placed in a cooler for transport to the laboratory. In total 216 bulk density samples and 216 bagged samples were taken $(12$ trees $\times 3$ litter sample areas $\times 2$ depths $\times 3$ replicates).

\section{Soil analysis}

Field moist bulk density samples were weighed and dried in an oven at $105{ }^{\circ} \mathrm{C}$ for $24 \mathrm{~h}$ in the soil laboratory of the Escuela Internacional de Agricultura y Ganadería (EIAG) in Rivas. Soil bulk density was calculated by dividing the dry sample weight by $100 \mathrm{~cm}^{3}$ (core method; (Burt 2004). Bagged samples were air-dried at the laboratory in Belén, roots were picked out, samples were ground and homogenized and prepared for shipping to the laboratory at Wageningen University, The Netherlands.
The three bagged soil samples collected at each depth per subplot were mixed and homogenized yielding a total of 72 composite samples. After grinding, subsamples of the composited samples were analysed for total organic $\mathrm{C}$ and $\mathrm{N}$ with an element analyser (Interscience EA 1108). Organic and available $\mathrm{P}$ was determined according to Novozamsky et al. (1983). In short, samples were digested by subsequent additions of a selenium-sulphuric acid mixture and peroxide while heated to $330{ }^{\circ} \mathrm{C}$ (Gerhardt Kjeldatherm digestion system). After dilution of the digest, $\mathrm{P}$ was determined colorimetrically (spectrophotometer Mechatronics Starrcol SC-60-S at $720 \mathrm{~nm}$ ).

Subsamples were subjected to density fractionation to obtain the following organic matter fractions: free light fraction (fLF), occluded light fraction (oLF) and mineral associated heavy fraction (maHF). Briefly, $10 \mathrm{~g}$ air dried soil $<2 \mathrm{~mm}$ was shaken in a centrifuge tube with $50 \mathrm{ml}$ sodium polytungstate $\left(3 \mathrm{Na}_{2} \mathrm{WO}_{4}\right.$ $\left.9 \mathrm{WO}_{3} \cdot \mathrm{xH}_{2} \mathrm{O} ; \mathrm{SPT}\right)$ solution of density $1.6 \mathrm{~g} / \mathrm{cm}^{3}$. The samples were centrifuged for $23 \mathrm{~min}$ at $4500 \mathrm{rpm}$ $(5900 \times g)($ MSE Mistral 6000). The supernatant was poured over a Büchner funnel with a $0.7 \mu \mathrm{m}$ Whatman GF/F glass filter using a Millipore vacuum filtration unit (Millipore, Bedford, MA). The light fraction was rinsed off the filter into a glass beaker and oven dried at $40{ }^{\circ} \mathrm{C}$. Next, SPT solution was added to the residual soil material and shaken by hand to bring the precipitate into solution. An ultrasonic probe was used for $5 \mathrm{~min}$ to break the soil aggregates and to disperse the oLF. The suspension was centrifuged for $23 \mathrm{~min}$ at $4500 \mathrm{rpm}$. The centrifuged tubes were decanted over a Büchner funnel with a $0.7 \mu \mathrm{m}$ Whatman GF/F glass filter. The oLF fraction was rinsed off the filter into a glass beaker and oven dried at $40{ }^{\circ} \mathrm{C}$. The remaining precipitate, the maHF fraction, needed to be rinsed thoroughly in order to remove all STP. Total $\mathrm{C}, \mathrm{N}$ and $\mathrm{P}$ contents of each fraction were determined similarly as for the whole soil samples.

Field soil respiration measurements were done between August 3-September 6 and October 20November 2, 2010 (PP Systems, SRC-1 soil respiration chamber and EGM-4 $\mathrm{CO}_{2}$ monitor and temperature probe). Time series of soil respiration $\left(\mu \mathrm{mol} \mathrm{CO}_{2} / \mathrm{m}^{2} / \mathrm{s}\right)$ and temperature $\left({ }^{\circ} \mathrm{C}\right)$ based on hourly measurements between approximately 1 and $5 \mathrm{pm}$ were determined in each subplot (open pasture, tree canopy, leaf litter cone). These $\mathrm{CO}_{2}$ soil efflux 
measurements included root respiration and respiration due to microbial decomposition of litter and SOM. The average of each time series was used for further statistical analysis.

Statistical analysis

All data were plotted (histograms and Q-Q plots) and examined for outliers and normality (Field 2014). No data needed to be excluded or transformed. Because the subplots are not independent (affected by the same tree), a mixed design ANOVA was used with withinsubjects factor "litter deposition" (3 levels) and between-subjects factor "tree species". For each soil depth increment, the mixed ANOVA was implemented in IBM SPSS Statistics 22 by defining a Repeated Measures General Linear Model (Field 2014). Main or interaction effects were considered to be significant when the $P$ value of the F-test was $<0.05$. Significant main or interaction effects are presented as footnotes to the respective figures and tables.

\section{Results}

\section{Soil C, N and P}

Litter deposition affected soil $\mathrm{C}, \mathrm{N}$ and $\mathrm{P}$ contents at 0-20 cm depth increment (Fig. 2), with higher $\mathrm{C}$ and $\mathrm{N}$ contents in the canopy and leaf litter subplots as compared to pasture (both $P<0.001$ ), while $\mathrm{P}$ content was higher in the leaf litter subplots as compared to pasture and canopy $(P<0.001)$. Tree species did not affect soil $\mathrm{C}, \mathrm{N}$ and $\mathrm{P}$ content, but litter deposition $\times$ tree species interactions were significant for $\mathrm{C}$ and $\mathrm{N}(P=0.007$ and 0.001$)$ with larger $\mathrm{C}$ and $\mathrm{N}$ contents under Jícaro canopy. Litter deposition also affected soil $\mathrm{C}: \mathrm{N}, \mathrm{C}: \mathrm{P}$ and $\mathrm{N}: \mathrm{P}$ stoichiometry with lower $\mathrm{C}: \mathrm{N}(P=0.043)$ and higher $\mathrm{C}: \mathrm{P}$ and $\mathrm{N}: \mathrm{P}$ ratios (both $P=0.001$ ) under the canopy.

In the subsoil (Fig. 3), $\mathrm{C}$ content was larger under the canopy and in the leaf litter cone as compared to pasture $(P=0.040)$, while $\mathrm{N}$ and $\mathrm{P}$ contents were not affected by litter deposition. However, tree species and its interaction with litter deposition affected $\mathrm{C}$ and $\mathrm{N}$ contents, with larger subsoil $\mathrm{C}$ and $\mathrm{N}$ contents under Jícaro $(P=0.007$ and 0.010$)$. Subsoil $P$ content was not affected by tree species either. Despite no direct effect on subsoil $\mathrm{P}, \mathrm{P}$ related stoichiometry was affected by tree species with higher $\mathrm{C}: \mathrm{P}$ and $\mathrm{N}: \mathrm{P}$ ratios under Jícaro $(P=0.006$ and 0.020$)$.

\section{Soil organic matter fractions}

Soil fractionation yielded the distribution of $\mathrm{C}, \mathrm{N}$ and $\mathrm{P}$ over the free light, occluded light and mineral associated heavy fractions (fLF, oLF and maHF; Tables 1, 2, 3). On average, a very large fraction $(>90 \%)$ of organic C, N and P is present in the maHF of the topsoils. In the subsoil, this mineral associated fraction is even larger ( $>95 \%)$, emphasizing the importance of SOM stabilization by adsorption of organic matter onto mineral surfaces in these soils.

Litter deposition affected $\mathrm{C}, \mathrm{N}$ and $\mathrm{P}$ of the free light fractions resulting in more labile soil $\mathrm{C}, \mathrm{N}$ and $\mathrm{P}$ under the canopy and in the litter cone as compared to pasture $(P=0.001,0.007$ and $<0.001)$ at $0-20 \mathrm{~cm}$ soil depth (Table 1). Litter deposition $\times$ tree species interaction and tree species did not affect fLF C, N or P of the top soil. In the subsoil, only a tree species effect occurred with more available $\mathrm{P}$ under Guácimo as compared to Jícaro $(P=0.012)$.

With respect to the occluded fraction at $0-20 \mathrm{~cm}$ soil depth, litter deposition increased $\mathrm{C}$ and $\mathrm{N}$ under the canopy and in the litter cone as compared to pasture $(P=0.046$ and 0.048$)$, while $\mathrm{P}$ only increased underneath the canopy $(P=0.002)$. The litter deposition $\times$ tree species interaction resulted in higher $\mathrm{P}$ oLF values underneath Guácimo canopies. Moreover, Guácimo yielded higher oLF C and $\mathrm{P}(P=0.049$ and 0.046). In the subsoil, litter deposition only increased oLF $\mathrm{C}$ in the litter cone $(P=0.044)$, while Jícaro increased oLF N $(P=0.030)$.

Of the most stable SOM fractions at $0-20 \mathrm{~cm}, \mathrm{C}$ was larger under the canopy and in the litter cone as compared to pasture $(P=0.008)$, while $\mathrm{P}$ was larger only underneath the canopy $(\mathrm{P}=0.002)$. Just litter deposition did not affect $\mathrm{N}$ maHF, but he interaction litter deposition $\times$ tree species yielded higher $\mathrm{N}$ maHF under Jícaro canopies $(\mathrm{P}=0.009)$. Tree species had opposing effects on $\mathrm{N}$ and $\mathrm{P}$ maHF, where Jícaro increased $\mathrm{N} \quad(P=0.022)$ and Guácimo increased $\mathrm{P}$ maHF $(P=0.049)$. In the subsoil, the stable $\mathrm{C}$ fraction was found to be smaller under the canopy $(P=0.009)$. Tree species had also opposing effects on $\mathrm{N}$ and $\mathrm{P}$ maHF in the subsoil, with again 


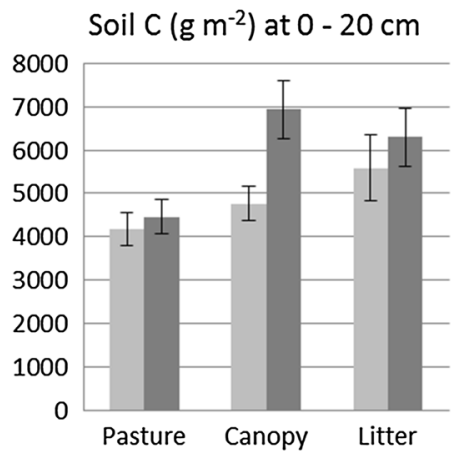

Soil C:N at $0-20 \mathrm{~cm}$

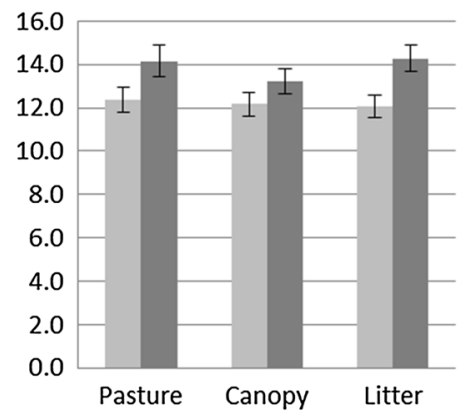

Soil $\mathrm{N}\left(\mathrm{g} \mathrm{m}^{-2}\right)$ at $0-20 \mathrm{~cm}$

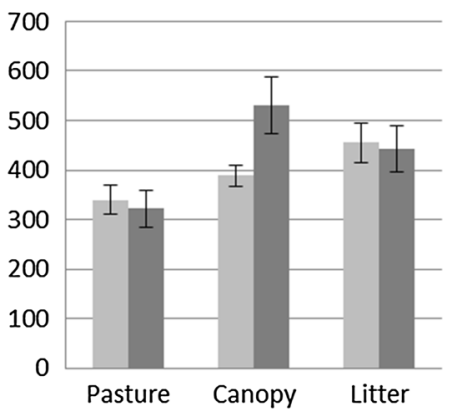

Soil C:P at $0-20 \mathrm{~cm}$

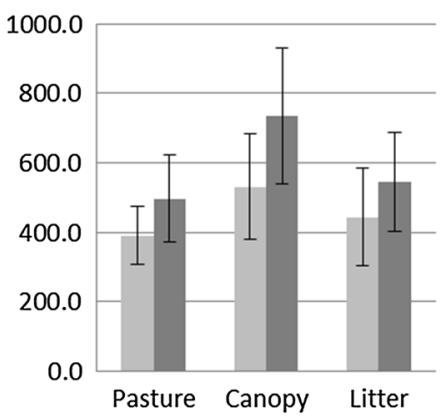

Soil $\mathrm{P}\left(\mathrm{g} \mathrm{m}^{-2}\right)$ at $0-20 \mathrm{~cm}$

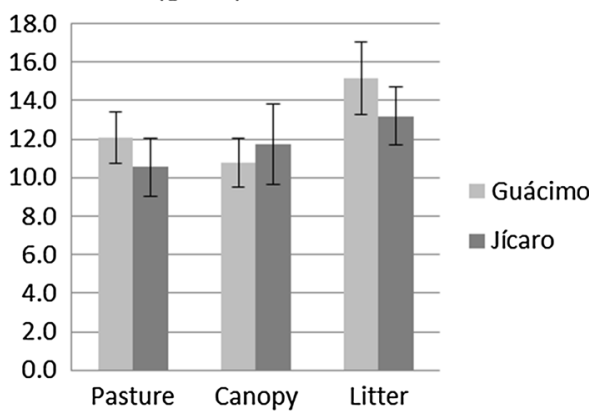

Soil N:P at $0-20 \mathrm{~cm}$

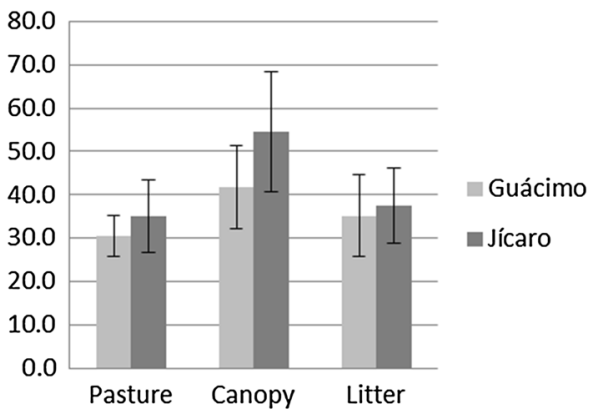

Fig. 2 Effects of litter deposition (open pasture, under canopy, leaf litter cone) and tree species on soil C, N and P contents and C N P stoichiometry at 0-20 cm depth. Error bars represent +1 and -1 standard error. Litter deposition effect on soil $\mathrm{C}, \mathrm{N}$ and $\mathrm{P}$ contents (all three $P<0.001$ ). Litter deposition $\times$ tree species

larger $\mathrm{N}$ under Jícaro $(P=0.0220)$ and larger $\mathrm{P}$ under Guácimo $(P=0.0024)$.

Soil respiration

Soil $\mathrm{CO}_{2}$ efflux rates were averaged over time for each subplot and were found to be larger in the litter cone and pasture subplots as compared to underneath the canopy $(P<0.001$; Table 4$)$, which coincides with lower soil temperatures underneath the canopy. Furthermore, soil respiration was marginally larger under Guácimo $(P=0.085)$.

\section{Discussion}

\section{Soil C, N and P}

The presence of trees, as compared to pasture, caused larger topsoil $\mathrm{C}$ and $\mathrm{N}$ contents in the areas affected by the tree, i.e. under the canopy and in the litter cone, effect on soil $\mathrm{C}$ and $\mathrm{N}$ contents $(P=0.007$ and 0.001$)$. Litter deposition effect on soil $\mathrm{C}: \mathrm{N}, \mathrm{C}: \mathrm{P}$ and N:P $(P=0.043,0.001$ and 0.001). Litter deposition $\times$ tree species effect on soil C:N $(P=0.046)$

while $\mathrm{P}$ was larger in the litter cone. In the subsoil, $\mathrm{C}$ content was also larger due to tree presence. In addition, the interaction between litter deposition and tree species showed larger $\mathrm{C}$ and $\mathrm{N}$ contents under Jícaro in both the top- and subsoil. The trees also affected soil stoichiometry. In the topsoil, lower C:N ratios point at larger tree induced $\mathrm{N}$ availability, while higher $\mathrm{C}: \mathrm{P}$ and $\mathrm{N}: \mathrm{P}$ ratios suggest depletion of $\mathrm{P}$. In the subsoil, $\mathrm{P}$ related stoichiometry showed $\mathrm{P}$ depletion under Jícaro.

The larger tree-induced soil $\mathrm{C}$ and $\mathrm{N}$ contents may be due to the higher net primary productivity and leaf litter production of systems with trees as compared to pasture vegetation only, because multi-strata systems have higher resource uptake and photosynthetic capacity (Chapin et al. 2012). Working in SPS in the Matagalpa district in central Nicaragua, Casals et al. (2014) also observed soil C and N contents to be larger under trees as compared to open pasture and, based on $\delta^{13} \mathrm{C}$ analysis, attributed this to higher above- and belowground litter inputs from trees. Also, based on 


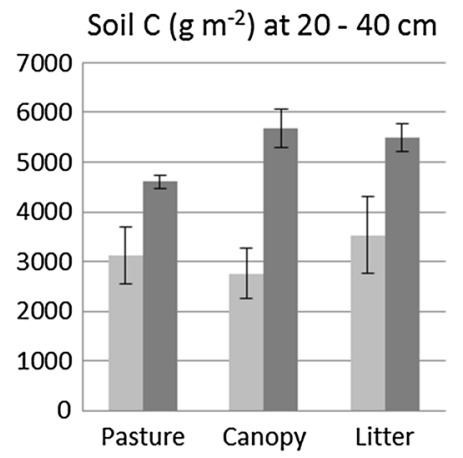

Soil C:N $\left(\mathrm{g} \mathrm{m}^{-2}\right)$ at $20-40 \mathrm{~cm}$

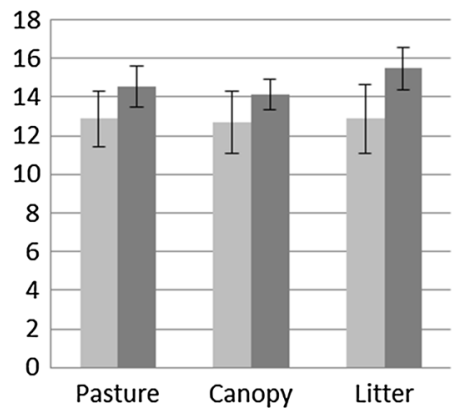

Soil N $\left(\mathrm{g} \mathrm{m}^{-2}\right)$ at $20-40 \mathrm{~cm}$

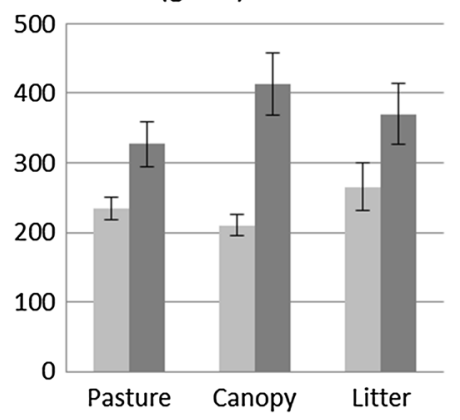

Soil C:P $\left(\mathrm{g} \mathrm{m}^{-2}\right)$ at $20-40$

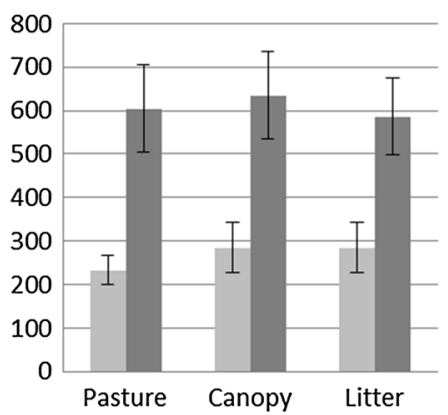

Soil $\mathrm{P}\left(\mathrm{g} \mathrm{m}^{-2}\right)$ at $20-40 \mathrm{~cm}$

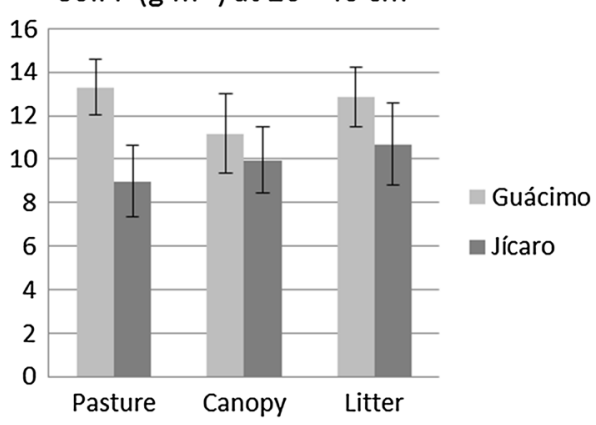

Soil $\mathrm{N}: \mathrm{P}\left(\mathrm{g} \mathrm{m}^{-2}\right)$ at $20-40 \mathrm{~cm}$

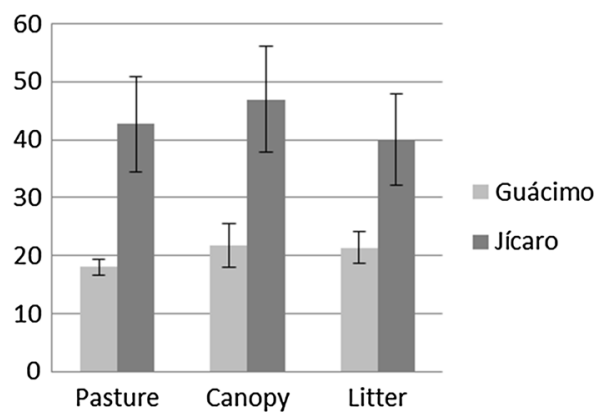

Fig. 3 Effects of litter deposition (open pasture, under canopy, leaf litter cone) and tree species on soil $\mathrm{C}, \mathrm{N}$ and $\mathrm{P}$ contents and C N P stoichiometry at $20-40 \mathrm{~cm}$ depth. Error bars represent +1 and -1 standard error. Litter deposition effect on soil $\mathrm{C}$ content $(P=0.040)$. Litter deposition $\times$ tree species effect on soil $\mathrm{C}$ and $\mathrm{N}$ contents $(P=0.019$ and 0.008$)$. Tree species effect on soil $\mathrm{C}: \mathrm{P}$ and $\mathrm{N}: \mathrm{P}$ ratios $(P=0.006$ and 0.020$)$

Table 1 Effects of litter deposition and tree species on free light C, N and P SOM fractions (fLF)

\begin{tabular}{|c|c|c|c|c|c|c|c|c|}
\hline \multirow[t]{2}{*}{ Depth $(\mathrm{cm})$} & \multirow[t]{2}{*}{ Litter deposition } & \multirow[t]{2}{*}{ Tree species } & \multicolumn{2}{|c|}{$\mathrm{C}(\mathrm{mg} / \mathrm{g})$} & \multicolumn{2}{|c|}{$\mathrm{N}(\mathrm{mg} / \mathrm{g})$} & \multicolumn{2}{|l|}{$\mathrm{P}(\mathrm{mg} / \mathrm{g})$} \\
\hline & & & Mean & SE & Mean & SE & Mean & SE \\
\hline \multirow[t]{6}{*}{$0-20$} & \multirow[t]{2}{*}{ Pasture } & Guácimo & 0.691 & 0.102 & 0.0181 & 0.0017 & 0.00102 & 0.00012 \\
\hline & & Jícaro & 0.614 & 0.080 & 0.0143 & 0.0022 & 0.00065 & 0.00010 \\
\hline & \multirow[t]{2}{*}{ Canopy } & Guácimo & 0.961 & 0.119 & 0.0224 & 0.0024 & 0.00106 & 0.00017 \\
\hline & & Jícaro & 0.759 & 0.075 & 0.0228 & 0.0027 & 0.00095 & 0.00022 \\
\hline & \multirow[t]{2}{*}{ Litter } & Guácimo & 0.989 & 0.127 & 0.0266 & 0.0039 & 0.00134 & 0.00017 \\
\hline & & Jícaro & 0.795 & 0.055 & 0.0228 & 0.0031 & 0.00107 & 0.00019 \\
\hline \multirow[t]{6}{*}{$20-40$} & \multirow[t]{2}{*}{ Pasture } & Guácimo & 0.216 & 0.022 & 0.0034 & 0.0008 & 0.00033 & 0.00005 \\
\hline & & Jícaro & 0.243 & 0.052 & 0.0049 & 0.0013 & 0.00019 & 0.00006 \\
\hline & \multirow[t]{2}{*}{ Canopy } & Guácimo & 0.158 & 0.020 & 0.0026 & 0.0005 & 0.00030 & 0.00002 \\
\hline & & Jícaro & 0.174 & 0.017 & 0.0048 & 0.0010 & 0.00015 & 0.00005 \\
\hline & \multirow[t]{2}{*}{ Litter } & Guácimo & 0.241 & 0.028 & 0.0045 & 0.0010 & 0.00031 & 0.00011 \\
\hline & & Jícaro & 0.191 & 0.022 & 0.0050 & 0.0009 & 0.00011 & 0.00002 \\
\hline
\end{tabular}

Litter deposition effect on free light $\mathrm{C}(P=0.001), \mathrm{N}(P=0.007)$ and $\mathrm{P}(P<0.001)$ at $0-20 \mathrm{~cm}$ depth

Tree species effect on free light $\mathrm{P}(P=0.012) \mathrm{SOM}$ fraction at $20-40 \mathrm{~cm}$ depth 
Table 2 Effects of litter deposition and tree species on occluded light C, N and P SOM fractions (oLF)

\begin{tabular}{|c|c|c|c|c|c|c|c|c|}
\hline \multirow[t]{2}{*}{ Depth $(\mathrm{cm})$} & \multirow[t]{2}{*}{ Litter deposition } & \multirow[t]{2}{*}{ Tree species } & \multicolumn{2}{|c|}{$\mathrm{C}(\mathrm{mg} / \mathrm{g})$} & \multicolumn{2}{|c|}{ N (mg/g) } & \multicolumn{2}{|l|}{ P (mg/g) } \\
\hline & & & Mean & SE & Mean & SE & Mean & SE \\
\hline \multirow[t]{6}{*}{$0-20$} & \multirow[t]{2}{*}{ Pasture } & Guácimo & 2.278 & 0.558 & 0.0448 & 0.0125 & 0.00193 & 0.00046 \\
\hline & & Jícaro & 1.142 & 0.271 & 0.0290 & 0.0039 & 0.00098 & 0.00008 \\
\hline & \multirow[t]{2}{*}{ Canopy } & Guácimo & 3.237 & 0.919 & 0.0640 & 0.0193 & 0.00298 & 0.00070 \\
\hline & & Jícaro & 1.499 & 0.266 & 0.0422 & 0.0076 & 0.00100 & 0.00007 \\
\hline & \multirow[t]{2}{*}{ Litter } & Guácimo & 3.183 & 0.759 & 0.0653 & 0.0152 & 0.00151 & 0.00050 \\
\hline & & Jícaro & 1.298 & 0.238 & 0.0307 & 0.0033 & 0.00098 & 0.00012 \\
\hline \multirow[t]{6}{*}{$20-40$} & \multirow[t]{2}{*}{ Pasture } & Guácimo & 0.471 & 0.102 & 0.0072 & 0.0011 & 0.00029 & 0.00006 \\
\hline & & Jícaro & 0.603 & 0.089 & 0.0179 & 0.0025 & 0.00036 & 0.00005 \\
\hline & \multirow[t]{2}{*}{ Canopy } & Guácimo & 0.562 & 0.097 & 0.0090 & 0.0017 & 0.00034 & 0.00004 \\
\hline & & Jícaro & 0.581 & 0.086 & 0.0189 & 0.0040 & 0.00035 & 0.00007 \\
\hline & \multirow[t]{2}{*}{ Litter } & Guácimo & 0.787 & 0.107 & 0.0135 & 0.0017 & 0.00037 & 0.00006 \\
\hline & & Jícaro & 0.712 & 0.144 & 0.0169 & 0.0035 & 0.00030 & 0.00007 \\
\hline
\end{tabular}

Litter deposition effect on occluded light $\mathrm{C}(P=0.046), \mathrm{N}(P=0.048)$ and $\mathrm{P}(P=0.002)$ at $0-20 \mathrm{~cm}$ depth

Litter deposition $\times$ tree species effect on occluded light $\mathrm{P}(P=0.003)$ at $0-20 \mathrm{~cm}$ depth

Tree species effect on occluded light $\mathrm{C}(P=0.049)$ and $\mathrm{P}(P=0.046)$ at $0-20 \mathrm{~cm}$ depth

Litter deposition effect on occluded light $\mathrm{C}(P=0.044)$ at $20-40 \mathrm{~cm}$ depth

Tree species effect on occluded light $\mathrm{N}(P=0.030)$ at $20-40 \mathrm{~cm}$ depth

Table 3 Effects of litter deposition and tree species on mineral associated C, N and P SOM fractions (maHF)

\begin{tabular}{|c|c|c|c|c|c|c|c|c|}
\hline \multirow[t]{2}{*}{ Depth $(\mathrm{cm})$} & \multirow[t]{2}{*}{ Litter deposition } & \multirow[t]{2}{*}{ Tree species } & \multicolumn{2}{|c|}{$\mathrm{C}(\mathrm{mg} / \mathrm{g})$} & \multicolumn{2}{|c|}{$\mathrm{N}(\mathrm{mg} / \mathrm{g})$} & \multicolumn{2}{|c|}{$\mathrm{P}(\mathrm{mg} / \mathrm{g})$} \\
\hline & & & Mean & SE & Mean & SE & Mean & $\mathrm{SE}$ \\
\hline \multirow[t]{6}{*}{$0-20$} & \multirow[t]{2}{*}{ Pasture } & Guácimo & 31.49 & 4.45 & 1.345 & 0.246 & 0.2384 & 0.0365 \\
\hline & & Jícaro & 38.43 & 4.67 & 1.343 & 0.097 & 0.1162 & 0.0338 \\
\hline & \multirow[t]{2}{*}{ Canopy } & Guácimo & 34.83 & 4.86 & 1.155 & 0.219 & 0.2826 & 0.0409 \\
\hline & & Jícaro & 43.66 & 3.67 & 2.449 & 0.225 & 0.1785 & 0.0406 \\
\hline & \multirow[t]{2}{*}{ Litter } & Guácimo & 37.19 & 5.03 & 1.268 & 0.112 & 0.2288 & 0.0416 \\
\hline & & Jícaro & 45.77 & 4.42 & 1.977 & 0.378 & 0.1367 & 0.0222 \\
\hline \multirow[t]{6}{*}{$20-40$} & \multirow[t]{2}{*}{ Pasture } & Guácimo & 15.46 & 3.70 & 0.736 & 0.223 & 0.1543 & 0.0328 \\
\hline & & Jícaro & 23.79 & 1.60 & 1.351 & 0.165 & 0.0607 & 0.0242 \\
\hline & \multirow[t]{2}{*}{ Canopy } & Guácimo & 13.40 & 3.19 & 0.490 & 0.152 & 0.1247 & 0.0268 \\
\hline & & Jícaro & 19.35 & 1.44 & 1.210 & 0.177 & 0.0539 & 0.0203 \\
\hline & \multirow[t]{2}{*}{ Litter } & Guácimo & 14.26 & 3.37 & 0.821 & 0.205 & 0.1382 & 0.0257 \\
\hline & & Jícaro & 21.49 & 1.39 & 1.288 & 0.228 & 0.0535 & 0.0196 \\
\hline
\end{tabular}

Litter deposition effect on mineral associated $\mathrm{C}(P=0.008)$ and $\mathrm{P}(P=0.002)$ at $0-20 \mathrm{~cm}$ depth

Litter deposition $\times$ tree species effect on mineral associated $\mathrm{N}(P=0.009)$ at $0-20 \mathrm{~cm}$ depth

Tree species effect on mineral associated $\mathrm{N}(P=0.022)$ and $\mathrm{P}(P=0.049)$ at $0-20 \mathrm{~cm}$ depth

Litter deposition effect on mineral associated $C(P=0.009)$ at $20-40 \mathrm{~cm}$ depth

Tree species effect on mineral associated N $(P=0.022)$ and $\mathrm{P}(P=0.024)$ at $20-40 \mathrm{~cm}$ depth 
Table 4 Effects of litter deposition and tree species on $\mathrm{CO}_{2}$ efflux at the soil surface

Litter deposition effect on soil respiration $(P<0.001)$

Marginal tree species effect on soil respiration $(P=0.085)$

\begin{tabular}{|c|c|c|c|c|c|}
\hline \multirow[t]{2}{*}{ Litter deposition } & \multirow[t]{2}{*}{ Tree species } & \multicolumn{2}{|c|}{ Soil respiration $\left(\mu \mathrm{mol} / \mathrm{m}^{2} / \mathrm{s}\right)$} & \multicolumn{2}{|c|}{ Soil temperature $\left({ }^{\circ} \mathrm{C}\right)$} \\
\hline & & Mean & SE & Mean & SE \\
\hline \multirow[t]{2}{*}{ Pasture } & Guácimo & 9.23 & 0.60 & 29.4 & 0.1 \\
\hline & Jícaro & 6.69 & 0.56 & 29.6 & 0.1 \\
\hline \multirow[t]{2}{*}{ Canopy } & Guácimo & 4.87 & 0.67 & 27.3 & 0.0 \\
\hline & Jícaro & 3.91 & 0.50 & 27.3 & 0.0 \\
\hline \multirow[t]{2}{*}{ Litter } & Guácimo & 9.82 & 0.94 & 29.2 & 0.1 \\
\hline & Jícaro & 7.83 & 1.54 & 29.1 & 0.1 \\
\hline
\end{tabular}

soil profile $\delta^{13} \mathrm{C}$ values in SPS in Florida, USA, Haile et al. (2010) were able to show that trees (C3) contributed more $\mathrm{C}$ to the silt + clay-sized fraction $(<53 \mu \mathrm{m}$, which is comparable to the maHF in this study) than $\mathrm{C} 4$ grasses. This tree effect increased with soil depth.

As mentioned, soil $\mathrm{P}$ content was observed to be larger in the litter cone area as compared to pasture, while $\mathrm{P}$ depletion occurred underneath Jícaro. Obviously, $\mathrm{P}$ was taken up by Jícaro trees from underneath the canopy and subsequently released by leaf litterfall into the litter cone area. This mechanism may create differences in soil $\mathrm{P}$ content at relatively short distances $(3-5 \mathrm{~m})$, i.e. underneath the canopy versus litter deposition area. Working with isolated trees in a comparable Dehesa system, Gallardo (2003) also observed that isolated trees differentially affect the spatial distribution of nutrients, with $\mathrm{P}$ having a larger spatial range (beyond the canopy) as compared to $\mathrm{N}$ (within canopy projection). In this study however, this spatial differentiation was less pronounced for Guácimo trees, where, despite soil $\mathrm{P}$ enrichment in the leaf litter cone was observed, significant $\mathrm{P}$ depletion, based on higher $\mathrm{C}: \mathrm{P}$ and $\mathrm{N}: \mathrm{P}$ ratios in the canopy subplots, was not detected. Casals et al. (2014) found higher soil $P$ concentrations under the canopies of trees, including G. ulmifolia (Guácimo), in Central Nicaragua. Also, Martínez et al. (2014) working with SPS in Colombia observed higher available soil $\mathrm{P}$ levels in plots associated with trees, including G. ulmifolia (Guácimo), as compared to plots without trees. However, the results of these studies may still be in line with our study for Guácimo plots, when the spatial differentiation between $\mathrm{P}$ uptake and $\mathrm{P}$ input through litter deposition is less pronounced than in the Rivas area. The prevailing north-easterly winds coming across Lake Nicaragua caused a spatial differentiation between $\mathrm{P}$ uptake and deposition, which may be negligible in other areas. Still, taking spatial differences in account, trees enhance P cycling and available soil P stocks.

Soil organic matter fractions

A small part of the relatively fresh and unprotected OM (fLF) may become incorporated into aggregate structures (oLF) or become adsorbed onto mineral surfaces (maHF), while most of it will be decomposed and respired with $\mathrm{C}$ leaving the soil as $\mathrm{CO}_{2}$ and $\mathrm{N}$ and $\mathrm{P}$ being mineralized into plant available forms. Tree presence and its litterfall increased labile $\mathrm{C}, \mathrm{N}$ and $\mathrm{P}$ fractions (fLF) in the topsoil, which allows higher $\mathrm{N}$ and $\mathrm{P}$ fertility and larger input of $\mathrm{OM}$ to the occluded and mineral associated fractions (SOM stabilization). In the subsoil, only fLF P was affected with a larger labile $\mathrm{P}$ fraction under Guácimo. This species-induced difference is in line with the larger uptake of available $\mathrm{P}$ by Jícaro as discussed above.

By increasing free light $\mathrm{C}, \mathrm{N}$ and $\mathrm{P}$ fractions (fLF), tree presence also resulted, through increased soil fauna and microbial activity, in more soil aggregation and larger occluded light $\mathrm{C}, \mathrm{N}$ and $\mathrm{P}$ fractions. Also the larger $\mathrm{P}$ fLF due to Guácimo resulted in a larger $\mathrm{P}$ oLF under Guácimo, which may be due to higher litter $\mathrm{P}$ content of this tree or, as suggested above, relatively stronger P uptake by Jícaro. Differences in plant traits, i.e. leaf litter quality, may also have resulted in larger subsoil oLF $\mathrm{N}$ in the litter cone subplots of Jícaro.

During further decomposition of either free or occluded OM, relatively smaller organic molecules or even soluble organic $\mathrm{C}$ may become adsorbed onto mineral surfaces (Saidy et al. 2015; Von Lützow et al. 2006). The tree-induced larger free and occluded light $\mathrm{C}, \mathrm{N}$ and $\mathrm{P}$ fractions resulted in larger stabilized $\mathrm{C}$ and $\mathrm{P}$ fractions in the topsoil for both trees species, while stabilized $\mathrm{N}$ was enhanced under Jícaro. As for the 
whole soil $\mathrm{N}$ and $\mathrm{P}$ contents and the free and occluded $\mathrm{N}$ and $\mathrm{P}$ fractions, Jícaro enhanced the stabilized $\mathrm{N}$ fraction, while Guácimo enhanced stabilized $\mathrm{P}$ fractions at both soil depths. Mineralization and nutrient uptake by trees may have caused the somewhat lower $\mathrm{C}$ maHF in the canopy subsoil.

\section{Soil respiration}

The larger $\mathrm{CO}_{2}$ efflux in the leaf litter subplots as compared to underneath the canopy can obviously be attributed to the larger leaf litter input causing increased heterotrophic respiration. However, in the canopy subplots we expected some extra $\mathrm{CO}_{2}$ efflux by autotrophic tree root respiration, but obviously did not make up for the leaf litter effect. Also, lower soil temperatures underneath the canopy may have suppressed $\mathrm{CO}_{2}$ efflux. Although the respiration rates in the pasture subplots were lower than in the leaf litter subplots, the difference was not significant, which suggests that part of the extra $\mathrm{C}$ input to the leaf litter subplots may stay in the soil. The latter is supported by the whole soil and fractionation data that show that tree presence enhanced soil C content.

\section{Role of trees}

Our hypothesized role of trees in SPS was primarily confirmed by the effect of tree litter deposition causing topsoil C, N and P content to be larger in the canopy and litter cone subplots as compared to open pasture. Moreover, soil fractionation showed that tree-induced larger litter input subsequently increased free and occluded OM fractions and ultimately increased stabilized SOM fractions. Therefore, trees enhance soil C sequestration in these SPS. Casals et al. (2014) found similar results and also Haile et al. (2010) suggested that pastures with trees have greater potential to sequester more soil $\mathrm{C}$ as compared to treeless pastures. Although in colder ecosystems, in a review of studies in temperate and boreal forests Vesterdal et al. (2013) also found tree species effects on SOC stocks.

Both tree species enhanced nutrient cycling but had different effects on soil $\mathrm{N}$ and $\mathrm{P}$, where Jícaro enhanced available and stabilized $\mathrm{N}$ and Guácimo enhanced available and stabilized P. The study by Casals et al. (2014) included a larger diversity of tree species, but they concluded that the presence of trees increased soil $\mathrm{C}$ and fertility and that the magnitude of this effect depends more on tree size than on species traits like being leguminous or not. However, our results show a clear tree species effect on nutrient cycling which is most likely due to differences in functional traits (Augusto et al. 2015). From a management point of view, this and related studies clearly show that tree presence in these SPS contribute to soil $\mathrm{C}$ sequestration and nutrient availability. More specifically, the prevailing wind in the Rivas area and the resulting litter deposition causes differences in available organic $\mathrm{N}$ and $\mathrm{P}$ fractions at short distances. Moreover, choice between Jícaro versus Guácimo may enhance respectively soil $\mathrm{N}$ and $\mathrm{P}$ availability.

Acknowledgements We thank Dalia Sánchez Merlos for logistic support and Andreas Nieuwenhuyse for providing useful comments and insights during fieldwork. Mr Eef Velthorst is gratefully acknowledged for providing guidance in the laboratory and running part of the chemical analysis. Financial support was provided by the European Commission, Directorate General for the Environment, within the 7th Framework Programme of RTD, Theme 2-Biotechnology, Agriculture \& Food (Grant Agreement No. 227265 FUNCiTREE).

Open Access This article is distributed under the terms of the Creative Commons Attribution 4.0 International License (http:// creativecommons.org/licenses/by/4.0/), which permits unrestricted use, distribution, and reproduction in any medium, provided you give appropriate credit to the original author(s) and the source, provide a link to the Creative Commons license, and indicate if changes were made.

\section{References}

Andrade H, Brook R, Ibrahim M (2008) Growth, production and carbon sequestration of silvopastoral systems with native timber species in the dry lowlands of Costa Rica. Plant Soil 308:11-22

Augusto L, Schrijver AD, Vesterdal L, Smolander A, Prescott C, Ranger J (2015) Influences of evergreen gymnosperm and deciduous angiosperm tree species on the functioning of temperate and boreal forests. Biol Rev 90:444-466

Ballantyne AP, Alden CB, Miller JB, Tans PP, White JWC (2012) Increase in observed net carbon dioxide uptake by land and oceans during the past 50 years. Nature 488:70-72

Bullock SH, Mooney HA, Medina E (1995) Seasonally dry tropical forest. Cambridge University Press, New York

Burt R (2004) Soil survey laboratory methods manual. United States Department of Agriculture, Lincoln

Casals P, Romero J, Rusch G, Ibrahim M (2014) Soil organic C and nutrient contents under trees with different functional characteristics in seasonally dry tropical silvopastures. Plant Soil 374:643-659 
Chapin FS, Matson PA, Vitousek PM (2012) Pinciples of terrestrial ecosystem ecology, 2nd edn. Springer, New York

Cordero J, Boshier DH (eds) (2003) Árboles de Centroamérica. Un manual para extensionistas. Oxford Forestry Institute (OFI, Oxford University) and Centro Agronómico Tropical de Investigación y Enseñanza (CATIE), Oxford, UK and Turrialba

Dagang AK, Nair PKR (2003) Silvopastoral research and adoption in Central America: recent findings and recommendations for future directions. Agrofor Syst 59:149-155

Field A (2014) Discovering statistics using IBM SPSS statistics. Sage Publications, London

Flores OI, Bolivar DM, Botero JA, Ibrahim MA (1998) Parámetros nutricionales de algunas arbóreas leguminosas y no leguminosas con potencial forrajera para la suplementación de ruminantes en el trópico. Livest Res Rural Dev 10(1):1-10

Francis JK (1991) Guazuma ulmifolia Lam. Guácima. Sterculiaceae. Chocolate familiy. USDA Forest Service, Southern Forest Experiment Station, Institute of Tropical Forestry

Gallardo A (2003) Effect of tree canopy on the spatial distribution of soil nutrients in a Mediterranean Dehesa. Pedobiologia 47:117-125

Guevara S, Purata SE, Maarel EVd (1986) The role of remnant forest trees in tropical secondary succession. Vegetatio 66:77-84

Haile SG, Nair VD, Nair PKR (2010) Contribution of trees to carbon storage in soils of silvopastoral systems in Florida, USA. Glob Change Biol 16:427-438

Harvey CA, Haber WA (1998) Remnant trees and the conservation of biodiversity in Costa Rican pastures. Agrofor Syst 44:37-68

Holdridge LR (2000) Ecologia basada en zonas de vida. IICA, San José

INETER (2000) Zonificación de la III y IV región. Informe de Campo. Instituto Nicaragüense de Estudios Territoriales

Jobbágy EG, Jackson RB (2004) The uplift of soil nutrients by plants: biogeochemical consequences across scales. Ecology 85:2380-2389

Manning AD, Fischer J, Lindenmayer DB (2006) Scattered trees are keystone structures-implications for conservation. Biol Conserv 132:311-321

Martínez J, Cajas YS, León JD, Osorio NW (2014) Silvopastoral systems enhance soil quality in grasslands of Colombia. Appl Environ Soil Sci 2014:8
Novozamsky I, Houba VJG, Van Eck R, Van Vark W (1983) A novel digestion technique for multi-element plant analysis. Commun Soil Sci Plant Anal 14:239-248

Ospina S, Rusch GM, Pezo D, Casanoves F, Sinclair FL (2012) More stable productivity of semi natural grasslands than sown pastures in a seasonally dry climate. PLoS ONE 7:e35555

Pagiola S, Ramírez E, Gobbi J, de Haan C, Ibrahim M, Murgueitio E, Ruíz JP (2007) Paying for the environmental services of silvopastoral practices in Nicaragua. Ecol Econ 64:374-385

Rockwood LL (1974) Seasonal changes in the susceptibility of Crescentia Alata leaves to the flea beetle, Oedionychus sp. Ecology 55:142-148

Rusch GM, Zapata PC, Casanoves F, Casals P, Ibrahim M, DeClerck F (2014) Determinants of grassland primary production in seasonally-dry silvopastoral systems in Central America. Agrofor Syst 88:517-526

Saidy AR, Smernik RJ, Baldock JA, Kaiser K, Sanderman J (2015) Microbial degradation of organic carbon sorbed to phyllosilicate clays with and without hydrous iron oxide coating. Eur J Soil Sci 66:83-94

Sánchez D, López M, Medina A, Gómez R, Harvey CA, Vilchez S, Hernández B, López F, Joya M, Sinclair FL, Kunth S (2004) Importancia ecológica y socioeconómica de la cobertura arbórea en un paisaje fragmentado de bosque seco de Belén, Rivas, Nicaragua. Encuentro 36:7-12

Sánchez Merlos D, Harvey CA, Grijalva A, Medina A, Hernández B, Vílchez S (2005) Vegetation diversity, composition and structure in a cattle agro-landscape of Matiguás. Nicaragua. Int J Trop Biol 53(3-4):387-414

Sardans J, Peñuelas J (2013) Plant-soil interactions in Mediterranean forest and shrublands: impacts of climatic change. Plant Soil 365:1-33

Vesterdal L, Clarke N, Sigurdsson BD, Gundersen P (2013) Do tree species influence soil carbon stocks in temperate and boreal forests? For Ecol Manag 309:4-18

Von Lützow M, Kögel-Knabner I, Ekschmitt K, Matzner E, Guggenberger G, Marschner B, Flessa H (2006) Stabilization of organic matter in temperate soils: mechanisms and their relevance under different soil conditions-a review. Eur J Soil Sci 57:426-445 